\title{
Influence of different Ni coatings on the long-term behavior of ultrasonic welded EN AW 1370 cable/EN CW 004A arrestor dissimilar joints
}

\author{
Tobias Köhler $^{1}$ (D) $\cdot$ Michael Grätzel $^{1} \cdot$ Jean Pierre Bergmann ${ }^{1}$ \\ Received: 30 September 2020 / Accepted: 6 November 2020 / Published online: 23 November 2020 \\ (C) The Author(s) 2020
}

\begin{abstract}
The increasing demand for energy-efficient vehicles requires suitable methods for cost and weight reduction. This can be achieved by the replacement of copper by aluminum, in particular for the on-board power systems. However, the complete substitution is restricted by the mechanical and physical material properties of aluminum as well as challenges in the aluminum copper interface. The challenges concern the corrosion vulnerability and the occurrence of brittle intermetallic compounds (IMC) which can negatively influence the mechanical properties and the electrical conductivity. Therefore, current investigations focus on the one hand on the realization of dissimilar aluminum copper joints by suitable joining technologies, like ultrasonic welding, and on the other hand on the assurance of a sufficient prevention against harmful corrosion effects. In cases where the joint cannot be protected against corrosion by sealing, nickel coatings can be used to protect the joint. In the present study, the influence of electroless, electroplated, and sulfamate nickel coatings was investigated regarding the long-term stability. The joints were performed as industry-related arrester connections, consisting of EN AW 1370 cables and EN CW 004A terminals. The samples were exposed to corrosive as well as electrical, thermal, and mechanical stress tests according to current standards and regulations.
\end{abstract}

Keywords Ultrasonic welding $\cdot$ Aluminum $\cdot$ Copper $\cdot$ Eutectic phase $\cdot$ Long-term behavior

\section{Introduction}

In order to fulfill the current demands for reducing $\mathrm{CO}_{2}$ emissions, energy-efficient vehicles must be realized through approaches such as lightweight construction. By using electrically conductive materials with a lower density compared to the most commonly used material, copper, weight can be reduced. One approach is the substitution of copper by aluminum. Aluminum has a density which is about $70 \%$ lower than copper [1]. Since the conductivity of aluminum is lower than that of copper, the cross section of aluminum conductors must be increased by approximately $60 \%$. Despite the increase in the conductor cross section, it is possible to achieve a theoretical weight saving up to $50 \%$ [2]. Due to the properties of

Recommended for publication by Commission III - Resistance Welding, Solid State Welding, and Allied Joining Process

Jean Pierre Bergmann

info.fertigungstechnik@tu-ilmenau.de; jeanpierre.bergmann@tuilmenau.de

1 Technische Universität Ilmenau, Ilmenau, Germany aluminum, such as the creep behavior and its oxide layer, the substitution can only be partial. The contacts provided for consumers and energy suppliers remain made of copper. Therefore, there is a need for the production of mixed aluminum/copper compounds. Due to the properties of the two materials (different melting temperatures, different coefficients of thermal expansion, and different thermal conductivities, as well as the tendency to form brittle, intermetallic compounds with high specific electrical resistance), the manufacturing of these mixed joints is a challenge for joining technologies [1]; [3]; [4]; [5]. The use of friction-based solidstate welding processes such as friction stir welding (FSW) [6]; [7]; [8]; [9]; [10]; [11]; [12]; [13] or ultrasonic welding (USW) [14]; [15]; [16]; [17]; [18]; [19]; [20] can produce dissimilar material connections in several material combinations including $\mathrm{Al}$ and $\mathrm{Cu}$. The formation of brittle intermetallic phases such as $\mathrm{AlCu}$ and $\mathrm{Al}_{4} \mathrm{Cu}_{9}$ can be reduced when using ultrasonic welding by keeping the joining zone temperatures below the liquidus temperature of the joining partners [14]; [21]. During the lifetime of a vehicle, the ultrasonic welded joints are exposed to various environmental influences. Therefore, such joints are protected against the harmful 
Table 1 Process variables

\begin{tabular}{ll}
\hline Process variable & Value \\
\hline Amplitude $(\mu \mathrm{m})$ & 33.5 \\
Welding force $(\mathrm{kN})$ & $1.7 ; 2.0$ \\
Welding time $(\mathrm{ms})$ & $800 ; 1000 ; 1200$ \\
\hline
\end{tabular}

environmental influences in these industrial applications. This is achieved either by specific insulation of the joint by using protective plastic sealing or by the use of suitable coating of the copper elements. Nickel coatings, which act as a diffusion barrier between aluminum and copper, are frequently used for this purpose and can thus reduce corrosion [2]; [22]; [23]; [24]; [25]. These coatings can be distinguished by the type of nickel coating process, the composition of the electrolytes, the composition of the coating and the mechanical, chemical, and tribological properties. In this work, selected nickel types that are used in the industry (electroplated nickel, electroless nickel, and sulfamate nickel) are examined with regard to their suitability for maintaining the long-term stability of the compound.

The state of the art shows different investigations regarding ultrasonic welded aluminum/copper joints with coated joining partners as well as ultrasonic welding of aluminum and nickel. $\mathrm{Ni}$ et al. investigated the weldability and the mechanical properties of ultrasonic welded aluminum/nickel joints [26]. In their work, an improvement in tensile shear load by adding Al2219 particles between the interface of the aluminum and nickel sheets could be outlined [26]. Balasundaram et al. showed that $\mathrm{Al}-\mathrm{Cu}$ joints with a $\mathrm{Zn}$ interlayer in the interface can be characterized by a tensile shear load of $25-170 \%$ higher than samples without a $\mathrm{Zn}$ interlayer [27]. Regarding the aging of $\mathrm{Al} / \mathrm{Cu}$ joints without coating, Oberst et al. analyzed the aging mechanisms for bolted aluminum and copper busbar joints [28]. They showed that a higher temperature load leads to a faster deterioration of the connection and that

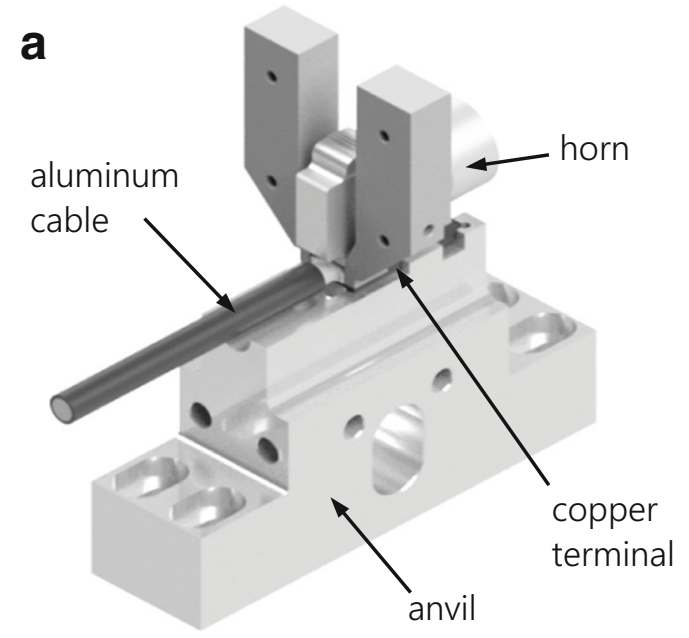

Fig. 1 Experimental setup the formed intermetallic compounds did not have a significant influence on the contact resistance [28]. Furthermore, Oberst et al. investigated the influence of different temperature loads on the building rates of $\mathrm{IMCs}$ for $\mathrm{Al} / \mathrm{Cu}$ joints, $\mathrm{Al} / \mathrm{Ni} / \mathrm{Cu}$ joints as well as other material combinations in order to determine a maximum temperature at which the connections can be used [29]. Bergmann et al. studied the influence of thermal load tests on ultrasonic welded aluminum wire-copper terminal connections considering different nickel coatings [2]. In their research, the welded samples were exposed to a thermal load of $350{ }^{\circ} \mathrm{C}$ for $45 \mathrm{~h}$. The authors showed a reduced failure load of up to $43 \%$ for nickel-plated samples and a reduced failure load of $60 \%$ for $\mathrm{Al} / \mathrm{Cu}$ joints without coating [2].

The analysis of the state of the art shows that the use of coatings for dissimilar $\mathrm{Al} / \mathrm{Cu}$ joints can have a positive influence on the mechanical properties and on the long-term stability. Hence, the objective of this work is to analyze the influence of various nickel types on the long-term behavior of the ultrasonic welded mixed cable-conductor connections. Those were investigated under thermal, corrosive, electrical, and vibration loads using conditions that will occur in the life cycle in an automotive environment. Therefore, test methods and standards from the automotive industry were used to test the samples according to the requirements of a life cycle.

\section{Experimental procedure}

The experiments were carried out on a linear ultrasonic welding machine that could realize a maximum power of $6.5 \mathrm{~kW}$ and a maximum welding force of $4 \mathrm{kN}$. The horn used has a square surface with an edge length of $16 \mathrm{~mm}$ and a corrugated profile. In this study, a time-controlled welding process was selected and performed with the welding parameters listed in Table 1. For the experimental procedure, EN AW 1370 cables with a cross section of $60 \mathrm{~mm}^{2}$ were used;

b

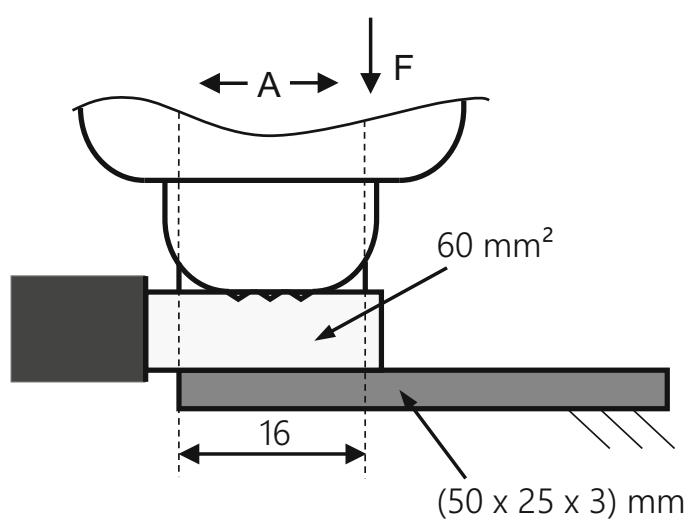


Table 2 Chemical composition EN CW $004 \mathrm{~A}$ in wt\% [30]

\begin{tabular}{llll}
\hline $\mathrm{Cu}$ & $\mathrm{Bi}$ & $\mathrm{O}$ & $\mathrm{Pb}$ \\
\hline$\geq 99.9$ & $\leq 0.0005$ & $\leq 0.04$ & $\leq 0.005$ \\
\hline
\end{tabular}

these had PVC insulation and were stripped $20 \mathrm{~mm}$ at each end of the cable. The total cable length was $300 \mathrm{~mm}$. The copper terminals used had a thickness of $3 \mathrm{~mm}$, a width of $22.5 \mathrm{~mm}$, and a length of $50 \mathrm{~mm}$. The sample arrangement of the cable-conductor connection for the welding experiment is shown in Fig. 1a and $b$.

Typical materials for battery technology and the automotive industry were used for welding the stranded wire-arrester connection. For example, a soft-annealed pure aluminum (EN AW 1370) was used as strand material and a copper sheet (EN $\mathrm{CW}$ 004A) as arrester, both with high corrosion resistance and electrical conductivity. The chemical compositions are shown in Table 2 and Table 3.

An electroless nickel with high phosphorus content, an additive-free electroplated nickel coating, and an electroplated sulfamate nickel (see Table 4) were selected for the coating of the copper terminals. The layer thickness for all coatings was set to $5 \mu \mathrm{m} \pm 1 \mu \mathrm{m}$, since a closed layer can be guaranteed from this layer thickness taking into account the variations. The samples were analyzed with an XRAY XDV-SDD device. The measurements were performed on three coated copper terminals with 24 measuring points per coating type. Figure 2 shows the layer thickness as a function of the type of coating. It can be seen that the measured layer thicknesses are above $5 \mu \mathrm{m}$ due to process variations. The variation of the layer thickness of electroplated and electroless nickel-plated samples is high in comparison to sulfamate nickel-plated samples.

The objective of this paper is to investigate the influence of different long-term tests on the joint quality of ultrasonic welded samples. The samples were subjected to electrical, corrosive, thermal, and vibration loads. In the context of the long-term tests on thermal load, the samples were thermally stored in an oven. Due to the requirements in an automotive vehicle, temperatures of $140{ }^{\circ} \mathrm{C}$ and $180^{\circ} \mathrm{C}$ were chosen and the samples were subjected to thermal testing for $500 \mathrm{~h}, 750 \mathrm{~h}$, and $1000 \mathrm{~h}$. The long-term behavior under current load was carried out in accordance with the UL 310 standard (see Fig. 3) [32]. Since this standard only specifies the test current for cables up to a maximum of $5.3 \mathrm{~mm}^{2}$, the current was

Table 3 Chemical composition EN AW 1370 in wt\% [31]

\begin{tabular}{lllllllll}
\hline $\mathrm{Al}$ & $\mathrm{Si}$ & $\mathrm{Fe}$ & $\mathrm{Cu}$ & $\mathrm{Mn}$ & $\mathrm{Cr}$ & $\mathrm{Mg}$ & $\mathrm{Zn}$ & $\mathrm{Ga}$ \\
\hline$\geq 99.7$ & $\leq 0.1$ & $\leq 0.25$ & $\leq 0.02$ & $\leq 0.01$ & 0.01 & $\leq 0.02$ & $\leq 0.04$ & $\leq 0.03$ \\
\hline
\end{tabular}

Table 4 Nickel coating types

\begin{tabular}{ll}
\hline Coating type & Additives \\
\hline Electroplated nickel & None \\
Electroless nickel & High phos \\
Sulfamate nickel & Sulfamate \\
\hline
\end{tabular}

adjusted according to the standard so that a node temperature of approx. $130{ }^{\circ} \mathrm{C}$ was reached. Thus, the test current determined amounted to $330 \mathrm{~A}$. The test consisted of 500 cycles, whereby one cycle consisted of $45 \mathrm{~min}$ with current load and $15 \mathrm{~min}$ without current load. The voltage for the resistance measurement was tapped at a distance of approximately $2 \mathrm{~mm}$ from the end of the cable. Furthermore, the temperature of the weld nodes was measured via thermocouples.

In order to test the influence of a vibration load on the longterm behavior of the ultrasonic welded stranded wireconductor connections, a vibration test according to VW standard 80000 M-04 [33] was carried out (see Fig. 4). The vibration profile D was selected for components mounted on suspended masses in the car chassis. Each dimensional direction was tested over a period of $8 \mathrm{~h}$. The long-term behavior under corrosive load was carried out according to DIN EN ISO 11130 [34]. In accordance with this standard, the samples were stored in a salt water solution. The salt solution was a mixture of $\mathrm{H}_{2} \mathrm{O}$ and $\mathrm{NaCl}$, of which $35 \mathrm{~g} \pm 1 \mathrm{~g} / \mathrm{l}$ salt was dissolved in water. The samples were tested after 250, 500, 750 , and 1000 cycles. In accordance with the standard, one cycle consisted of $10 \mathrm{~min}$ in the salt water solution and $50 \mathrm{~min}$ drying phase. Before each measurement, the samples were cleaned with clear water and stored for $24 \mathrm{~h}$ to dry.

After the long-term tests, the samples were tested by electrical, mechanical, and metallographic means. The measurements of the electrical resistance of the connections were performed based on the principle of the four-point measurement method (see Fig. 5). The measured values result from the sum

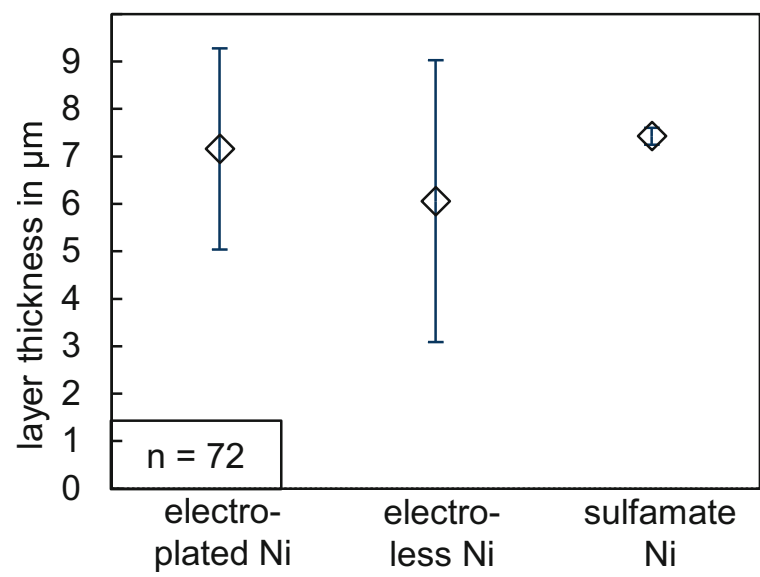

Fig. 2 Measured Ni layer thickness in dependence of the nickel types 
Fig. 3 Experimental setup of the electrical load tests (@ Stocko Contact AG)

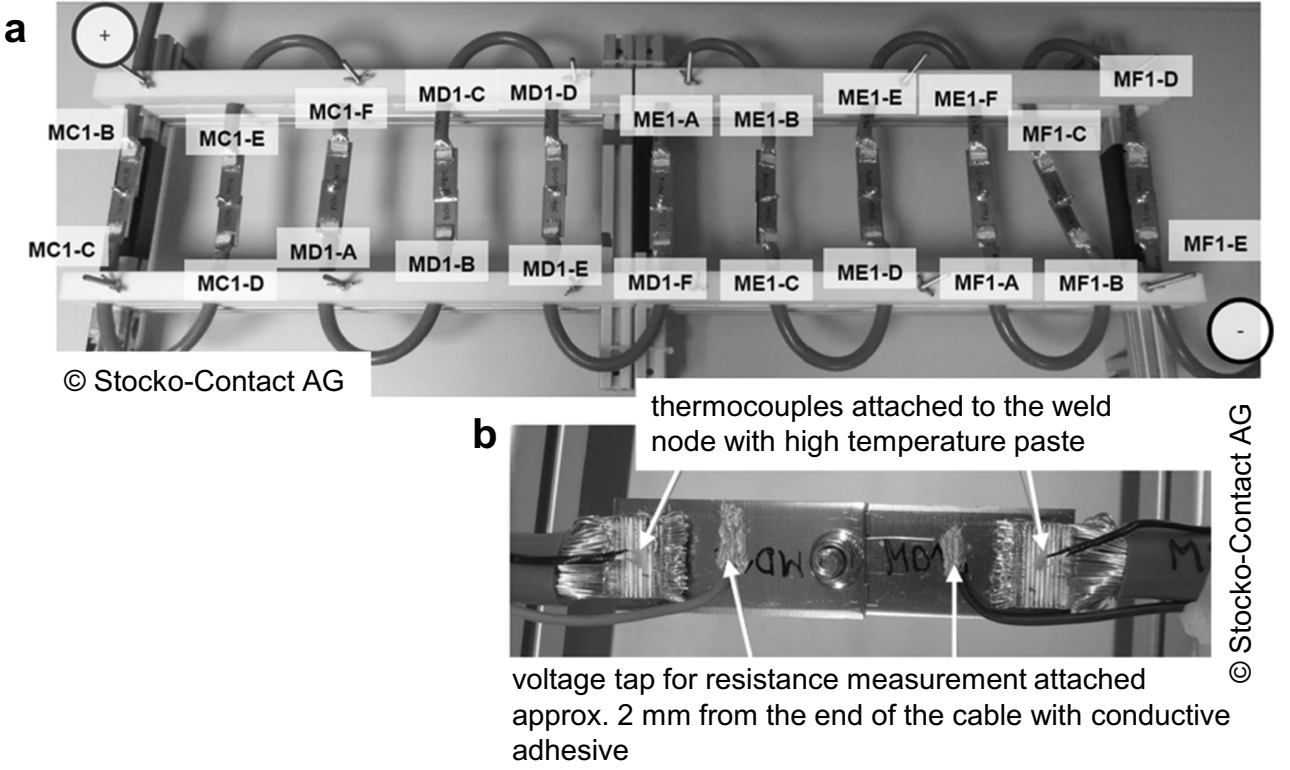

of the electrical resistances of the cable and two welded connections. The welded specimens were mechanically tested on a tensile testing machine with a maximum test load of $20 \mathrm{kN}$, a test speed of $10 \mathrm{~mm} / \mathrm{min}$, and a set force drop of $95 \%$. The free clamping length of the cables was set to $60 \mathrm{~mm}$.

\section{Results}

In this work, the focus is on the influence of the coating types on the long-term behavior of the welded joints. For this purpose, the samples were exposed to thermal, corrosive, and electrical loads and vibration tests.

\subsection{Corrosion test}

Depending on the application site, the material connection may come into contact with liquid. To simulate this corrosive load, a corrosive test in salt water according to ISO 11130 was performed. Specimens that were welded with the parameters $t=1000 \mathrm{~ms}, F=1.7 \mathrm{kN}$, and $A=33.5 \mu \mathrm{m}$ were tested for up to $1500 \mathrm{~h}$. Figure 6 shows the analysis of the influence of different types of coating on the electrical resistance as a function of the aging time. The specimens were electrically tested after $250 \mathrm{~h}, 500 \mathrm{~h}, 750 \mathrm{~h}, 1000 \mathrm{~h}$, and $1500 \mathrm{~h}$ aging time. In addition, the samples were mechanically tested after 1000 cycles. The measured value represents the electrical resistance of a cable connection with two welded Al-Cu connections. All coating types investigated can be described by an increase of the mean value and by the variation of the electrical resistance depending on the duration of the load. The largest increase in resistance from $R=142.5 \pm 1.9 \mu \Omega$ (as welded) to $R=158.7$ $\pm 4.9 \mu \Omega$ (1500 cycles) is observed on uncoated samples.

The data shown in the diagram indicate that all coated samples display an increase in electrical resistance. Taking electroplated samples as an example, it can be seen that the resistance here increases from $R=141.4 \pm 1.1 \mu \Omega$ (as welded) to $R=149.0 \pm 3.7 \mu \Omega$ (after 1500 cycles).

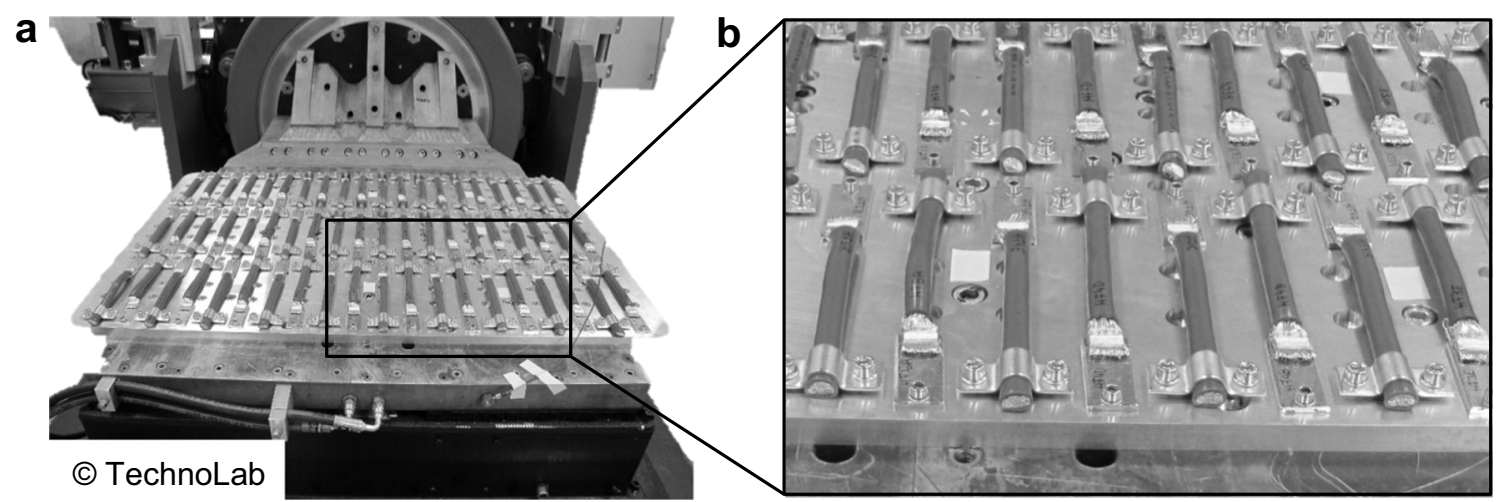

Fig. 4 Experimental setup of the vibration tests (@ TechnoLab GmbH) 
Fig. 5 Experimental setup for measuring the electrical resistance

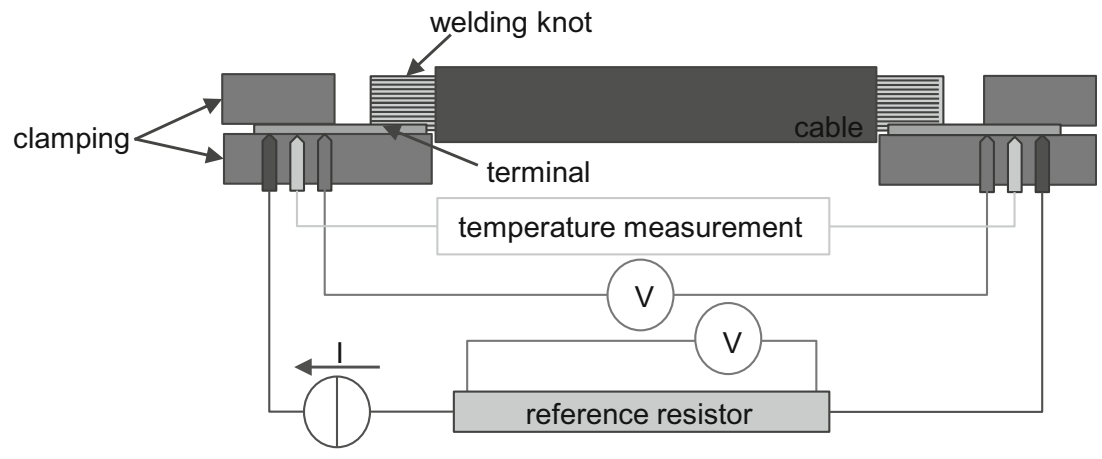

3.2 Electrical load test

In the next step, the influence of the long-term behavior under current load and the type of coating on the failure load and the electrical resistance were investigated. The current load tests were carried out according to the automotive standard UL 310. The tests were performed with specimens that were welded with a welding time of $t=1000 \mathrm{~ms}$, an amplitude of $A=33.5 \mu \mathrm{m}$, and the welding forces $F=1.7 \mathrm{kN}$ and $F=2.0$ $\mathrm{kN}$. Figure 8 shows the electrical resistance as a function of the type of coating and the welding force. The electrical resistance was measured for all samples before and after the 500 load cycles. The diagram also shows the node temperature during the electrical load test as a function of the abovementioned parameters. The temperature is shown for samples after one cycle (as welded) and after 500 cycles.

The results in Fig. 8 illustrate that the electrical resistance and the node temperature for uncoated samples increase slightly after the load test for samples joined with a welding force of $F=1.7 \mathrm{kN}$. In contrast, the influence of a welding force increased to $F=2.0 \mathrm{kN}$ leads to a comparatively stronger increase in electrical resistance and node temperature. For example, the electrical resistance of electroplated nickel samples increases from $R=168.7 \pm 4.5 \mu \Omega$ (as welded) to $F=$ $181.0 \pm 7.8 \mu \Omega$ (after 500 cycles) and the mean node temperature from $T=138.6 \pm 1.0{ }^{\circ} \mathrm{C}$ (as welded) to $T=143.8 \pm$

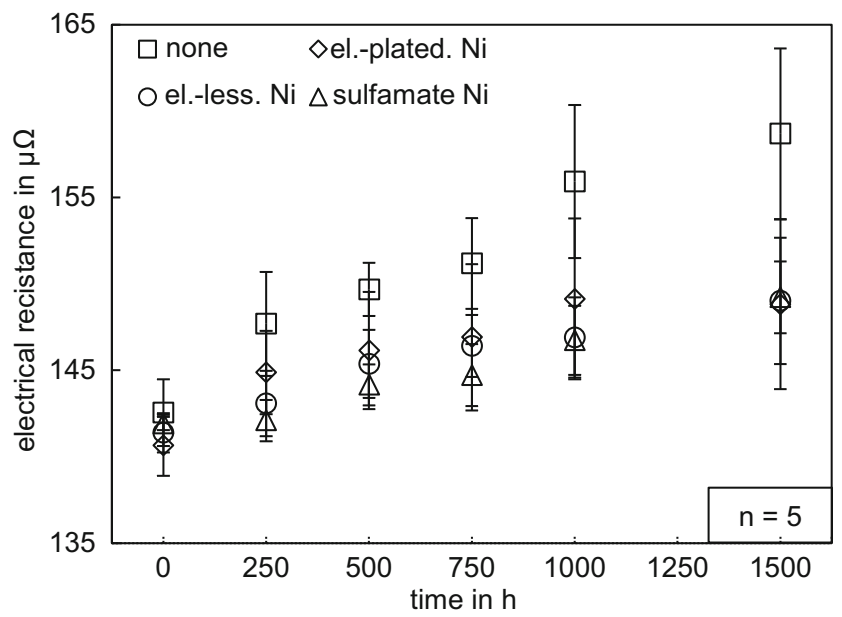

Fig. 6 Influence of the duration of the corrosion test and the type of coating on the electrical resistance of the welded samples $(t=1000 \mathrm{~ms}$; $F=1.7 \mathrm{kN} ; A=33.5 \mu \mathrm{m})$

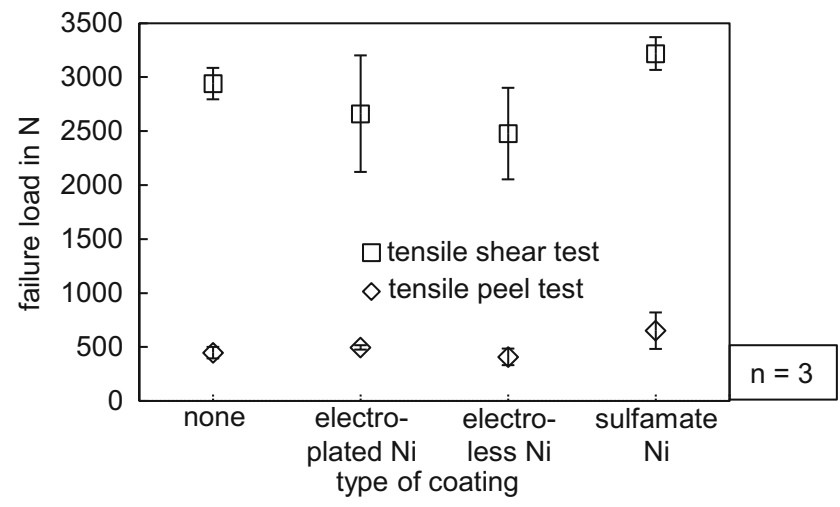

Fig. 7 Influence of the corrosion test and the type of coating on the tensile shear force and the tensile peel force $(t=1000 \mathrm{~ms} ; F=1.7 \mathrm{kN} ; A=$ $33.5 \mu \mathrm{m}$, aging time $=1000 \mathrm{~h}$ ) 
Fig. 8 Influence of the electrical load test and the welding force on the electrical resistance and the node temperature $(t=1000 \mathrm{~ms}$; $F=1.7 \mathrm{kN}$ and $2.0 \mathrm{kN} ; A=$ $33.5 \mu \mathrm{m})$

$1.0{ }^{\circ} \mathrm{C}$ (after 500 cycles). Thus, a significant influence of the welding parameters on the measured values can be recognized. This behavior can be seen for uncoated and for all coated samples that were examined. The increase of the node temperature can be attributed to the increase of the electrical resistance. The temperature load during the test can cause intermetallic phases with a higher specific electrical resistance to be formed, so that the node temperature increases as a result. A higher node temperature in return can lead to an increasing growth of intermetallic phases. The growing

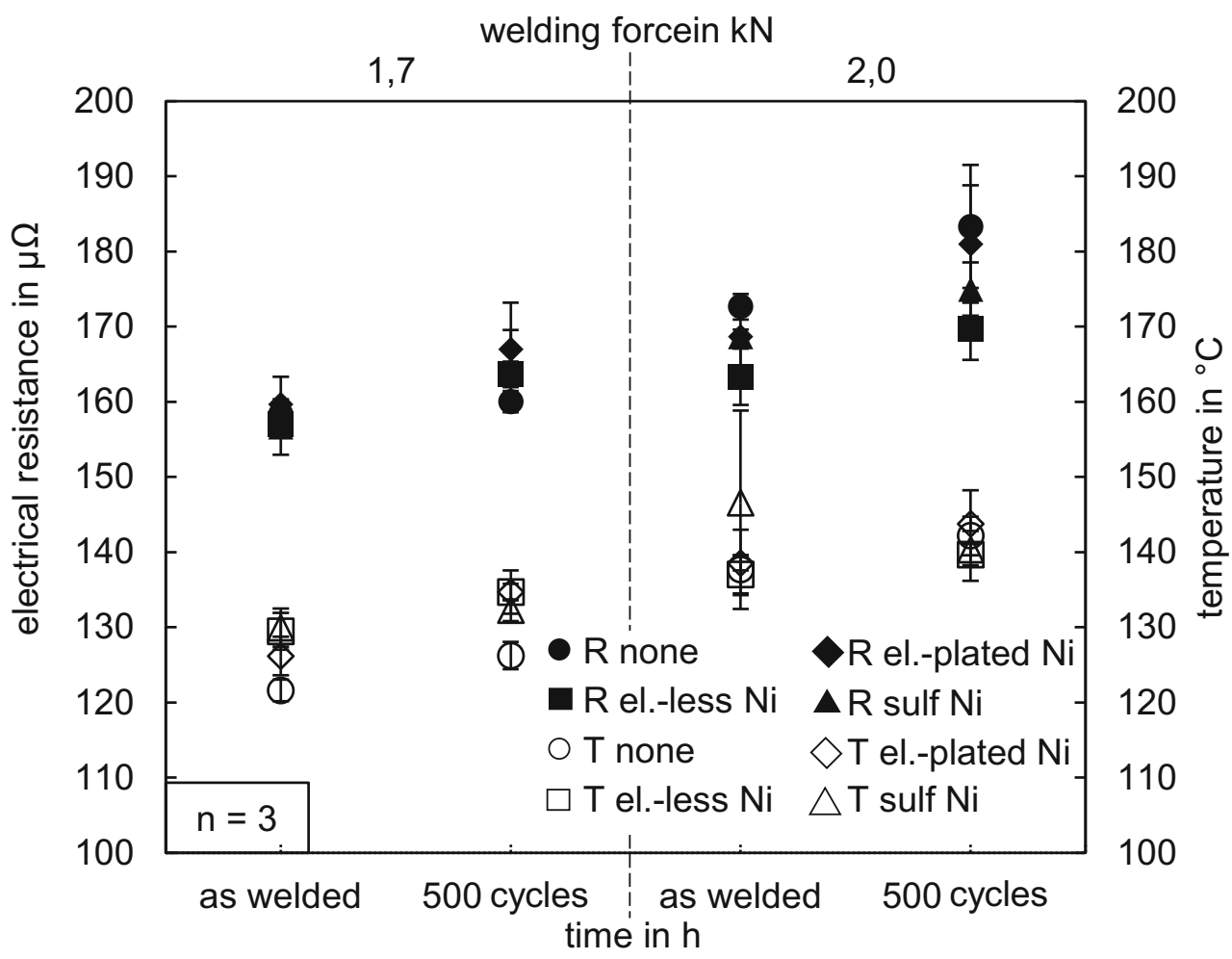

diffusion layer can be observed under the light microscope on uncoated samples (see Fig. 9 a). The increase in electrical resistance and the associated increase in node temperature also affect the mechanical properties of the samples due to the growth of intermetallic phases. The growth of a diffusion layer between $\mathrm{Al}$ and $\mathrm{Ni}$ could not be detected with a light microscope.

Figure 10 shows the failure load of the electrically tested and untested samples. It can be seen that a slight increase in the electrical resistance (see Fig. 8), with the selected load
Fig. 9 Metallographic analysis of the interface between aluminum and copper or nickel $(t=1000 \mathrm{~ms}$; $F=1.7 \mathrm{kN} ; 2.0 \mathrm{kN} ; A=33.5 \mu \mathrm{m}$; magnification $=\times 1000$ ). $\mathbf{a}$ Uncoated copper terminal. b Electroplated nickel-coated copper terminal. c Electroless nickelplated copper terminal. d

Sulfamate nickel-plated copper terminal

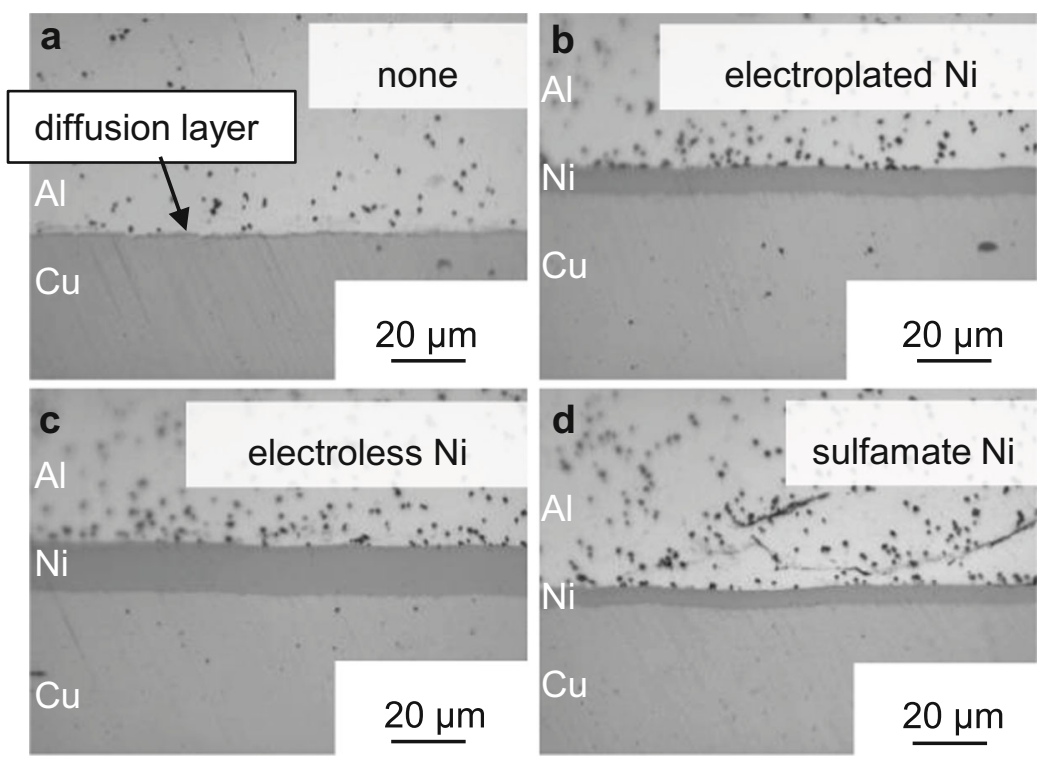


Fig. 10 Influence of the electrical load test and the welding force on the failure load $(t=1000 \mathrm{~ms} ; F=$ $1.7 \mathrm{kN}$ and $2.0 \mathrm{kN} ; A=33.5 \mu \mathrm{m})$

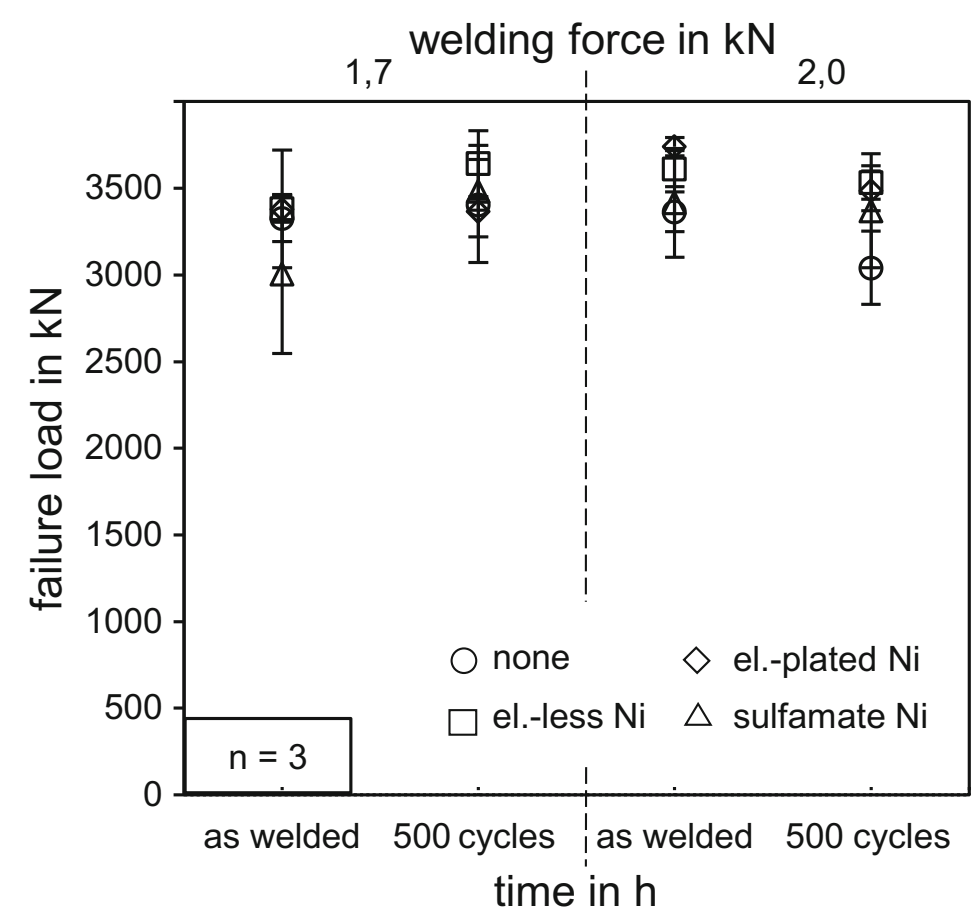

cycles, does not lead to any significant changes in the failure load of loaded samples compared to unloaded samples. This is the case with specimens welded with a welding force of $F=$
$1.7 \mathrm{kN}$. In comparison, the specimens which were joined with a welding load of $F=2.0 \mathrm{kN}$ show a reduction of failure load for uncoated and electroplated nickel-coated samples after the
Fig. 11 Failure behavior before and after 500 electric load cycles on welded cable-conductor connections; $t=1000 \mathrm{~s} ; F=1.7 \mathrm{kN}$; $A=33.5 \mu \mathrm{m}$

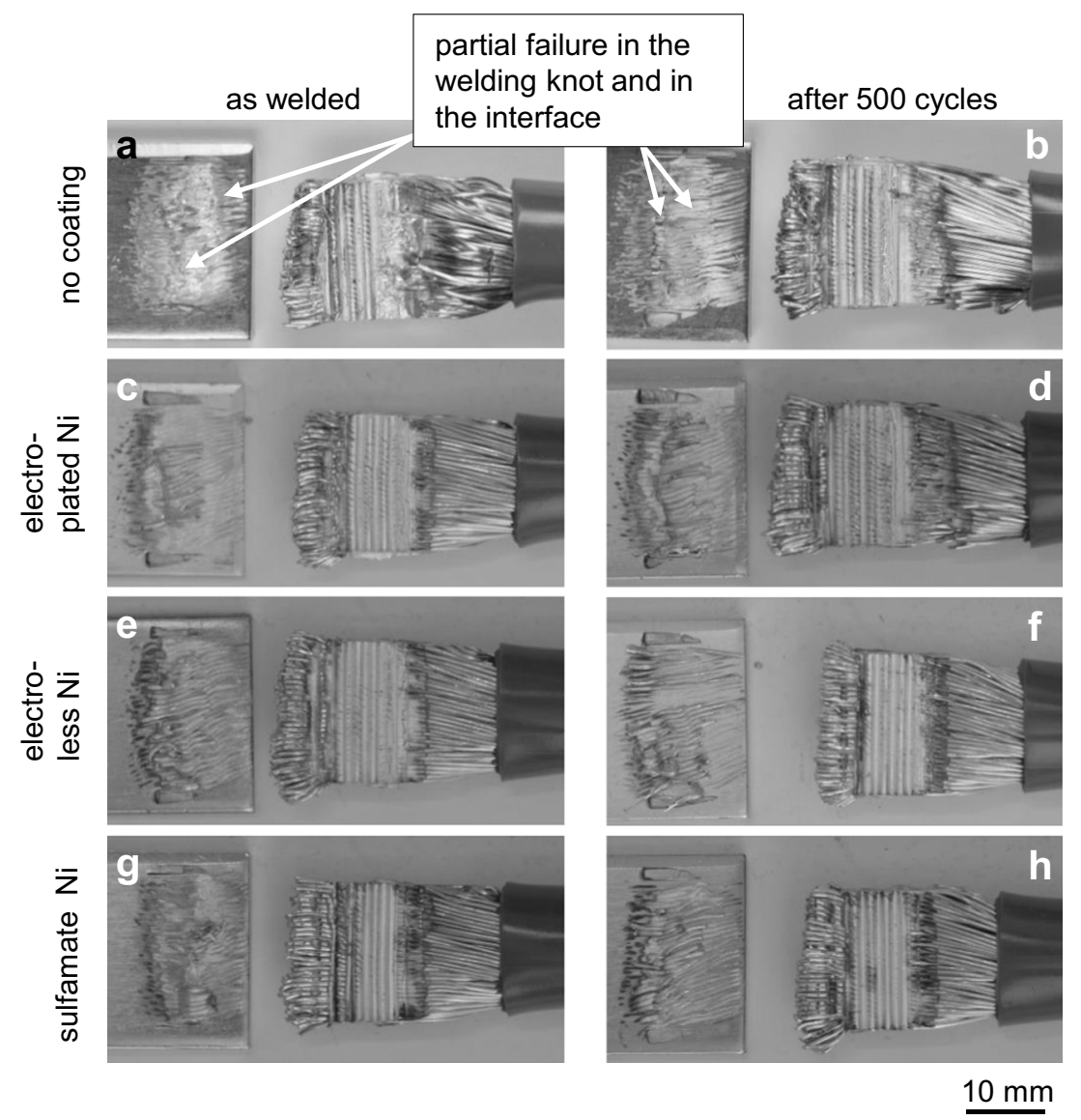



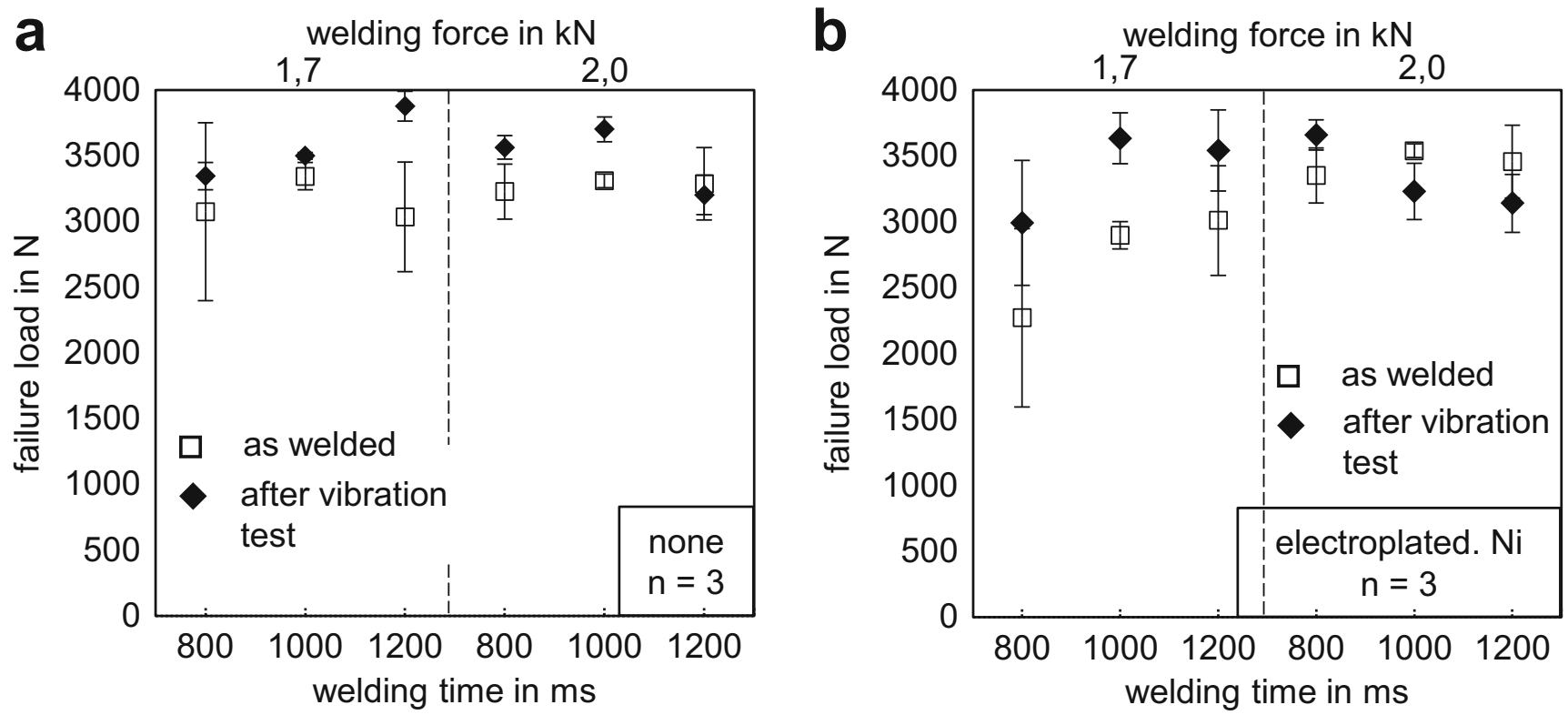

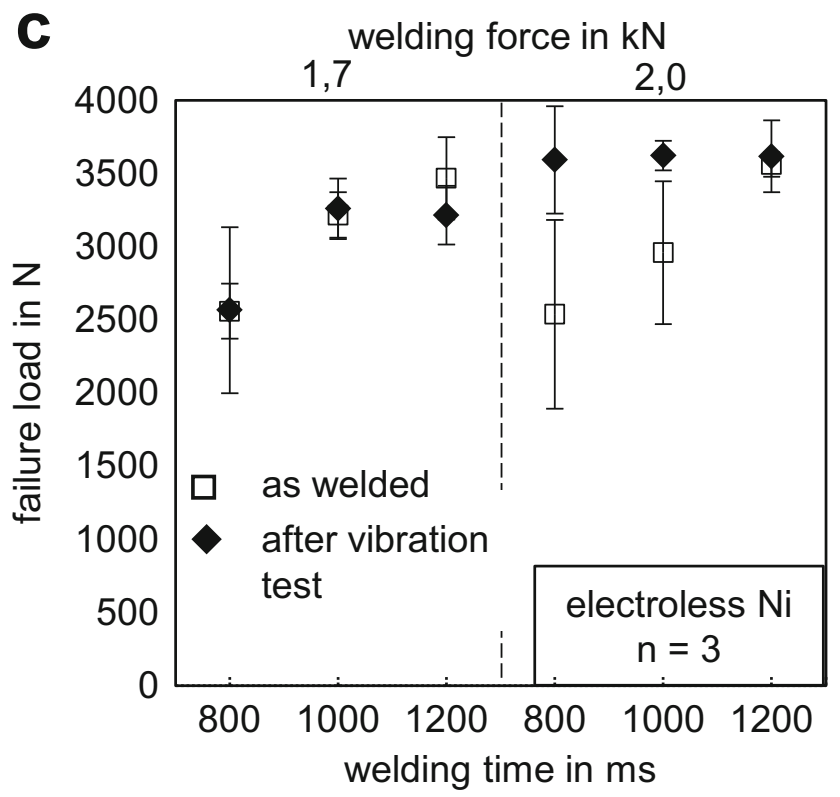

Fig. 12 Influence of the vibration test according to VW standard 80000 M-04 $\left(8 \mathrm{~h} /\right.$ room axis with $\left.\mathrm{a}_{\mathrm{e}}=30.8 \mathrm{~m} / \mathrm{s}^{2}\right)$ on the failure load of welded cable/conductor connections $(t=800 \mathrm{~s} ; 1000 \mathrm{~s} ; 1200 \mathrm{~s} ; F=1.7 \mathrm{kN} ; 2.0$ d

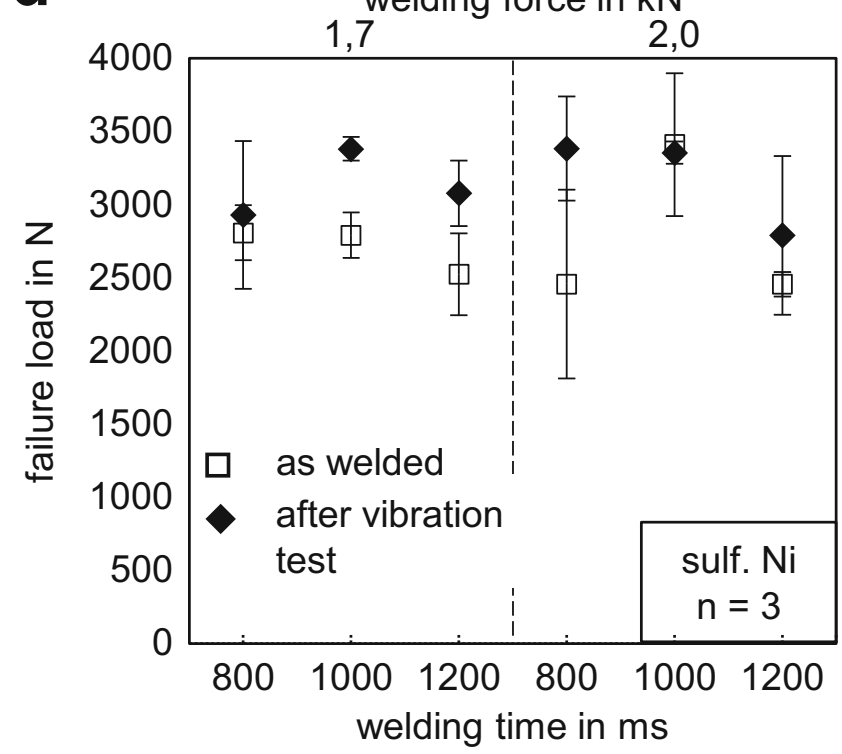

$\mathrm{kN} ; A=33.5 \mu \mathrm{m})$. a Uncoated samples. b Electroplated nickel-coated samples. c Electroless nickel-coated samples. d Sulfamate nickel-coated samples
Fig. 13 Failure behavior before and after vibration test according to VW standard $80000 \mathrm{M}-04(8 \mathrm{~h} /$ room axis with $\mathrm{a}_{\mathrm{e}}=30.8 \mathrm{~m} / \mathrm{s}^{2}$ ) on welded cable-conductor connections; $t=1000 \mathrm{~s} ; F=1.7 \mathrm{kN} ; A=$ $33.5 \mu \mathrm{m}$; electroless nickelcoated samples as welded

a

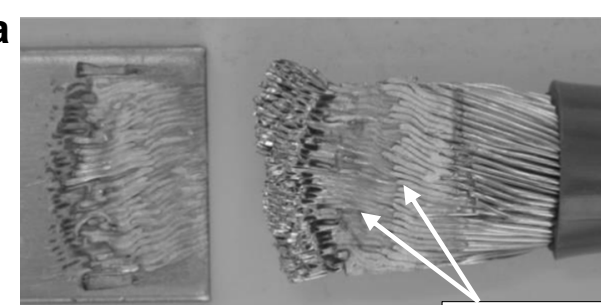

after vibration test

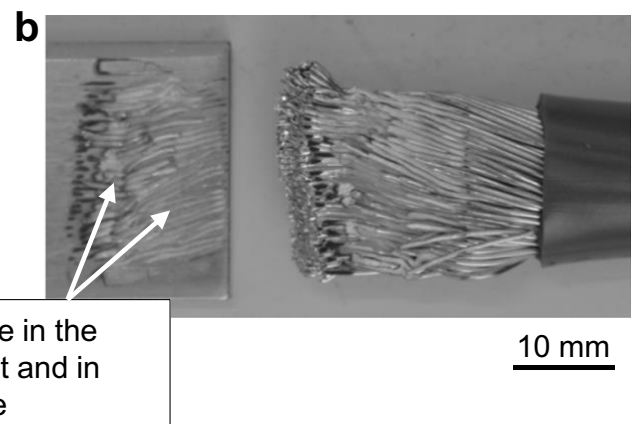

partial failure in the welding knot and in the interface 


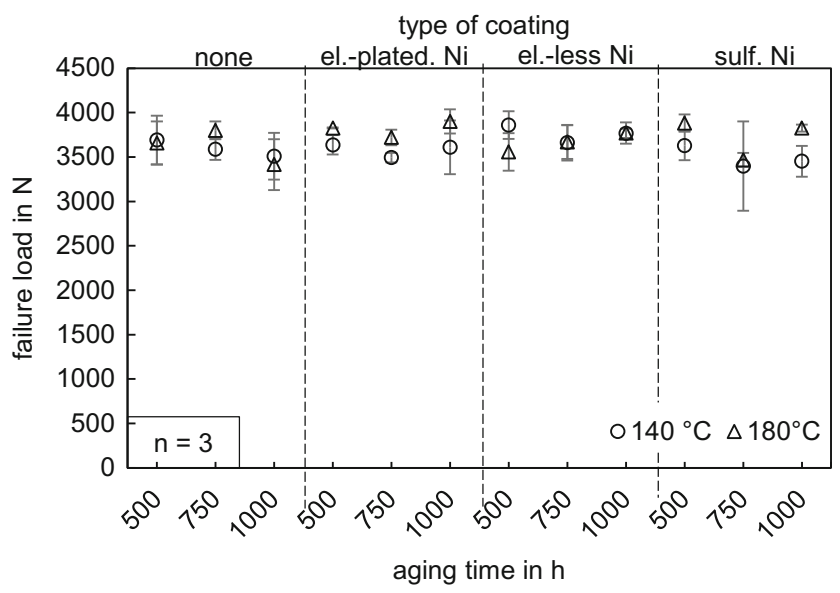

Fig. 14 Failure load as a function of the type of coating, the aging temperature, and the aging; $t=1000 \mathrm{~ms} ; F=1.7 \mathrm{kN} ; A=33.5 \mu \mathrm{m}$

current load. For example, the mean failure load for uncoated samples is reduced from $F=3365.0 \pm 115.0 \mathrm{~N}$ (as welded) to $F=3040.6 \pm 211.3 \mathrm{~N}$ (after 500 cycles). For electroless nickel-plated specimens and for sulfamate nickel-plated specimens, the failure load remains constant after the load test. In summary, it can be stated that no significant changes in the failure load due to the electrical load test were observed for any coating type tested. All changes in the failure load are above the minimum acceptable failure load according to SAE guideline USCAR 38 [35]. A similar behavior can be seen in the failure mode of the samples after the tensile test. Figure 11 shows the failure behavior before and after the electrical load test for all tested coating types for a welding time of $1000 \mathrm{~ms}$ and a welding force of $1.7 \mathrm{kN}$. The samples showed a similar partial failure behavior in the aluminum base material and in the interface between aluminum and copper or nickel before and after the electric load tests.

\subsection{Vibration test}

In the vehicle, the aluminum cables were exposed to different types of loads. Vibrations caused by driving and the engine can cause connections to fail. To test the influence of the coating type on the connection quality, the ultrasonic welded
Fig. 15 Cross-sectional images of thermally aged samples $\left(180^{\circ} \mathrm{C}\right.$, $1000 \mathrm{~h})(t=1000 \mathrm{~ms} ; F=1.7 \mathrm{kN}$; $A=33.5 \mu \mathrm{m})$. a Panoramic image of blank copper terminal. $\mathbf{b}-\mathbf{e}$ Light microscopic images $(x$ 1000 magnification). $\mathbf{f}-\mathbf{i}$ SEM images $(\times 11,000$ magnification $)$. $\mathbf{b}$ and $\mathbf{f}$ None coated copper terminal. $\mathbf{c}$ and $\mathbf{g}$ Electroplated nickel-coated copper terminal. d and $\mathbf{h}$ Electroless nickel-plated copper terminal. e and i Sulfamate nickel-plated copper terminal
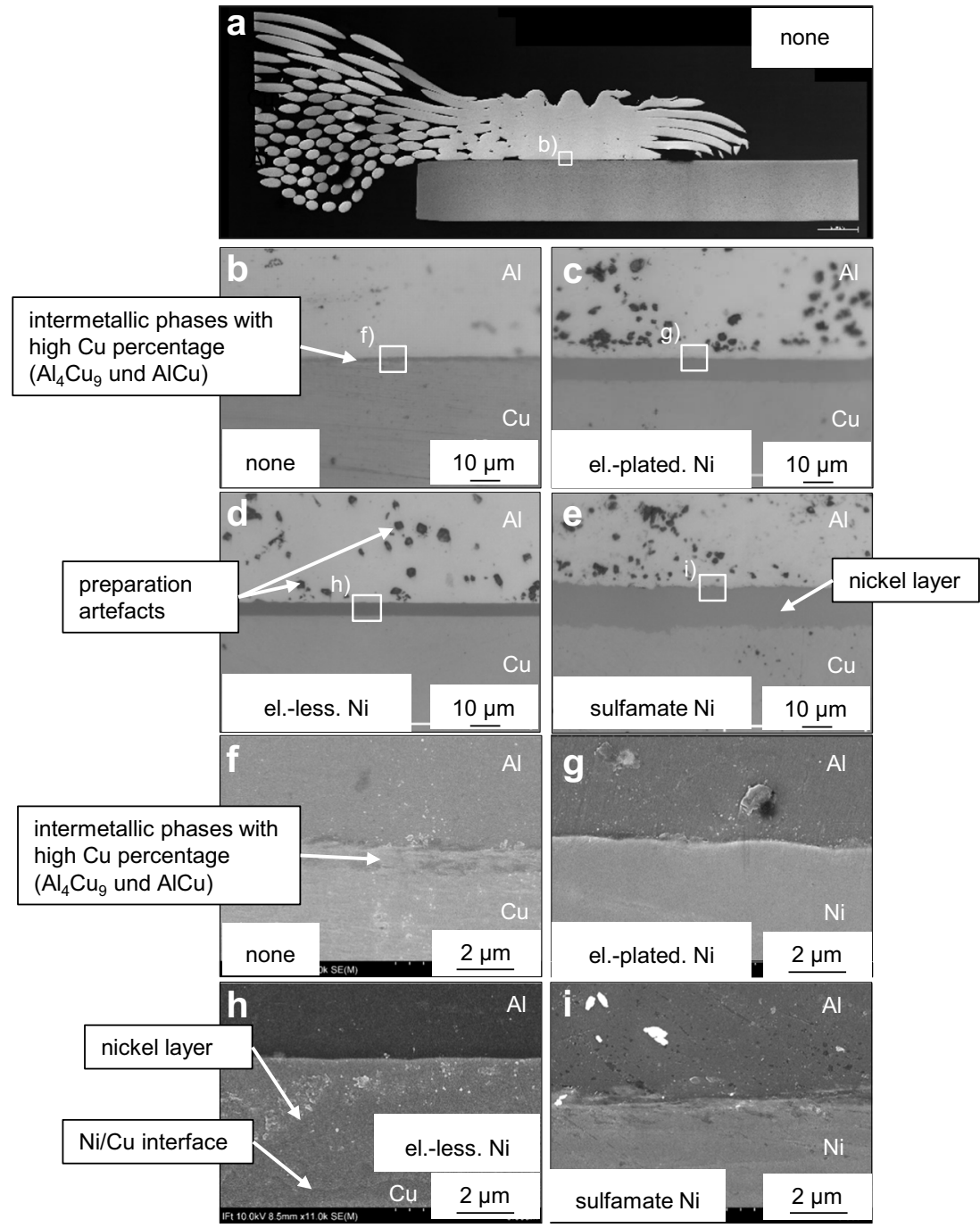


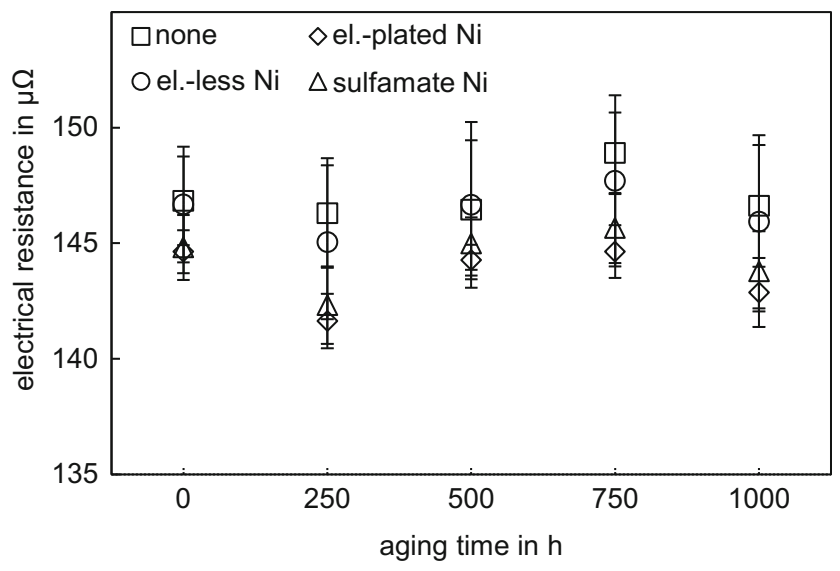

Fig. 16 Electrical resistance as a function of segregation duration at constant aging temperature $\left(180{ }^{\circ} \mathrm{C}\right) ; t=1000 \mathrm{~ms} ; F=1.7 \mathrm{kN} ; A=$ $33.5 \mu \mathrm{m}$

cable-arrester connections were exposed to a vibration test according to VW standard $80000 \mathrm{M}-04$.

Figure 12 shows the failure load before and after the vibration test as a function of welding time, welding force, and type of coating. Uncoated copper terminals (see Fig. 12 a), electroplated nickel-coated copper terminals (see Fig. 12 b), electroless nickel-coated copper terminals (see Fig. $12 \mathrm{c}$ ), and sulfamate nickel-coated terminals (see Fig. $12 \mathrm{~d}$ ) were examined. Comparing the failure loads before and after the vibration test of uncoated samples, it can be seen that no significant differences were found for almost all process variables investigated. Only samples that were joined with a welding force of $F=1.7 \mathrm{kN}$ and a welding time of $t=1200 \mathrm{~ms}$ show a higher average failure load after the vibration test. Since the vibration test has no positive effect on the mechanical properties, this effect can be explained by the general process uncertainties of the ultrasonic welding process. When looking at the samples coated with nickel, no influence of the type of coating can be detected. The failure load of both coated and uncoated samples is not adversely affected by the vibration test. This result can also be seen when considering the failure behavior of the samples before and after the vibration test (see Fig. 13). In Fig. 13, the failure behavior of electroless nickel-coated samples is considered as an example. The failure of the other coating types can be characterized by a similar behavior. A partial failure behavior in the interface and in the aluminum base material (welding node) can be determined. Hence, it can be proven that the samples are not significantly affected by the vibration test according to VW standard $80000 \mathrm{M}-04$, independent of the type of $\mathrm{Ni}$ coating. Despite the general process uncertainties, it was shown that the requirements for the failure load according to SAE guideline USCAR-38 (failure load $\geq 1800 \mathrm{~N}$ ) [35] were fulfilled for all tested samples before and after the vibration test.

\subsection{Thermal load test}

The thermal emissions in the vehicle and the heating of the connections due to the electrical resistance lead to thermal stress on the vehicle electrical system. The welded cablearrester connections were therefore exposed to thermal loads and then tested mechanically, metallographically, and electrically. The samples were stored at temperatures of $140^{\circ} \mathrm{C}$ and $180^{\circ} \mathrm{C}$ for $500 \mathrm{~h}, 750 \mathrm{~h}$, and $1000 \mathrm{~h}$. The samples tested were welded with a welding time of $t=1000 \mathrm{~ms}$, a welding force of $F=1.7 \mathrm{kN}$, and an amplitude of $A=33.5 \mu \mathrm{m}$. Figure 14 shows the failure load as a function of the aging temperature, the aging time, and the type of coating. In the case of uncoated specimens, it can be seen that there is a tendency towards a reduction of the failure loads with increasing aging time. However, due to the standard deviation of the values, no definitive conclusion can be drawn on this basis. Also, an influence of the aging temperature on the failure load cannot be detected due to the standard deviation. When considering the electroplated samples, it can be shown that a tendency towards higher failure loads is manifested with a thermal aging of $180{ }^{\circ} \mathrm{C}$.

The reduction of the failure loads with uncoated samples and the almost constant failure loads with coated samples can be explained by reference to the detailed images of the joining zone in Fig. 15. In the case of uncoated samples, the phases $\mathrm{Al}_{4} \mathrm{Cu}_{9}$ and $\mathrm{AlCu}$ were formed in the interface of the joining zone in the samples shown, which were aged for $1000 \mathrm{~h}$ at $180^{\circ} \mathrm{C}$ (see Fig. 15 a and Fig. 15 f). Due to the layer thickness of less than $2.5 \mu \mathrm{m}$, the phase seam has no negative effect on the mechanical properties of the compound [36]. The failure behavior of all aging temperatures and coating types in these tests can be described as a partial failure in the interface and in the aluminum base material similar to Fig. 11 and Fig. 13.

In addition to the mechanical and metallographic analysis of the samples, they were also tested by means of electrical resistance measurement. The results of this examination are shown in Fig. 16. In this figure, the electrical resistance is shown as a function of the aging time and the type of coating at a constant aging temperature of $180^{\circ} \mathrm{C}$. It can be seen that there are no significant changes in the electrical resistance over the aging period. Differences can be explained by the measuring inaccuracy of the measuring system and the comparatively high deviations. The electrical resistance of an uncoated sample after an aging period of $1000 \mathrm{~h}$ can be determined to $R=146.6 \pm 1.8 \mu \Omega$. The average resistance of electroplated nickel samples after $1000 \mathrm{~h}$ is $R=142.9 \pm 0.4$ $\mu \Omega$. In summary, it can be shown that no significant differences could be found under the aging conditions investigated and that there is no difference in whether a coating is used or which type of coating is used. 


\section{Conclusion}

In this paper, the influence of different nickel coatings on the long-term stability of ultrasonic welded $\mathrm{Al} / \mathrm{Cu}$ compounds was investigated. The long-term stability of the joints was tested according to current automotive industry standards based on thermal, corrosive, electrical, and vibration loads. As a result of the thermal load tests, it could be proven that no significant effects were found under the aging conditions investigated. In addition, no advantage of any particular type of coating could be identified. An electrical load test was also carried out. Here, an increase in electrical resistance and a reduction in the average failure load were detected after 500 load cycles for all coating types examined. In this case, the welding parameters (welding force and welding time) had a significant influence on the change in electrical resistance and the resulting failure load after the load test. Nevertheless, the changes in failure load are within the permissible range specified in the automotive standards UL310 and USCAR-38. The results of the corrosive immersion test can be summarized in such a way that the properties of the nickel layers as corrosion protection are given compared to uncoated samples. However, the difference in the change in electrical resistance between the uncoated and coated samples within the load cycles investigated can be neglected, since the coated samples are also negatively affected by the corrosive test. Finally, the longterm stability under a vibration load was investigated. After conducting the experiments according to VW Standard 80000 M-04, it was found that this test does not negatively affect the mechanical properties of the welded joints. In summary, it was shown that the influence of the coating types investigated in this study on the long-term stability of the joints was not significant. This means that both nickel-coated and uncoated copper terminals can be used for cable-conductor connections. Hence, consideration should be given to using uncoated samples in an industrial environment in order to reduce the production time and the production costs.

Acknowledgments Open Access funding enabled and organized by Projekt DEAL. The IGF Project No. 19485 BR/1 of the research association "Schweißen und verwandte Verfahren e.V." of the DVS, Aachener Straße 172, 40223 Düsseldorf was, on the basis of a resolution of the German Bundestag, promoted by the Federal Ministry of Economic Affairs and Energy via AiF within the framework of the program for the promotion of joint industrial research and development (IGF). In addition, the authors would like to thank the companies that supported the project for their contribution. We would like to thank Dr. H. Steinberg (Nexans Autoelectric) and the Telsonic AG for their support and the provision of materials. Special thanks also must be extended to the Stocko AG and Dr. C. d'Orléans for their support in carrying out the electrical long-term tests. Finally, the authors would like to thank Mrs. A. Kais and the students who collected and provided data for this research.

Funding The authors thank all the participants for the funding and the support.
Open Access This article is licensed under a Creative Commons Attribution 4.0 International License, which permits use, sharing, adaptation, distribution and reproduction in any medium or format, as long as you give appropriate credit to the original author(s) and the source, provide a link to the Creative Commons licence, and indicate if changes were made. The images or other third party material in this article are included in the article's Creative Commons licence, unless indicated otherwise in a credit line to the material. If material is not included in the article's Creative Commons licence and your intended use is not permitted by statutory regulation or exceeds the permitted use, you will need to obtain permission directly from the copyright holder. To view a copy of this licence, visit http://creativecommons.org/licenses/by/4.0/.

\section{References}

1. Braunovic M, Myshkin NK, Konchit VV (2007) Electrical contacts: fundamentals, applications and technology. Electrical and computer engineering, vol 132. Taylor \& Francis distributor, Boca Raton, Fla, London

2. Bergmann JP, Regensburg A, Schürer R, Petzoldt F, Herb A (2017) Effect of the interface characteristics on the joint properties and diffusion mechanisms during ultrasonic metal welding of $\mathrm{Al} / \mathrm{Cu}$. Weld World 61:499-506. https://doi.org/10.1007/s40194-0170449-6

3. Mokhtari O, Kim M-S, Nishikawa H, Kawashiro F, Itoh S, Maeda T, Hirose T, Eto T (2014) Investigation of formation and growth behavior of $\mathrm{Cu} / \mathrm{Al}$ intermetallic compounds during isothermal aging. Trans Jpn Inst Electron Packag 7:1-7. https://doi.org/10.5104/ jiepeng.7.1

4. Chen K, Meng WJ, Eastman JA (2014) Interface development in $\mathrm{Cu}$-based structures transient liquid phase (TLP) bonded with thin Al foil intermediate layers. Metall and Mat Trans A 45:3892-3906. https://doi.org/10.1007/s11661-014-2339-5

5. Braunovic M, Alexandrov N (1994) Intermetallic compounds at aluminum-to-copper electrical interfaces: effect of temperature and electric current. IEEE Trans Comp, Packag Manuf Technol A 17:78-85. https://doi.org/10.1109/95.296372

6. Galvão I, Loureiro A, Rodrigues DM (2016) Critical review on friction stir welding of aluminium to copper. Sci Technol Weld Join 21:523-546. https://doi.org/10.1080/13621718.2015.1118813

7. Köhler T, Schiele M, Glaser M, Schricker K, Bergmann JP, Augsburg K (2020) In-situ monitoring of hybrid friction diffusion bonded EN AW 1050/EN CW 004A lap joints using artificial neural nets. Proc Inst Mech Eng Part L J Mater Des Appl 234:766-785. https://doi.org/10.1177/1464420720912773

8. Regensburg A, Schürer R, Weigl M, Bergmann J (2018) Influence of pin length and electrochemical platings on the mechanical strength and macroscopic defect formation in stationary shoulder friction stir welding of aluminium to copper. Metals 8:85. https:// doi.org/10.3390/met8020085

9. Çam G (2011) Friction stir welded structural materials: beyond Alalloys. Int Mater Rev 56:1-48. https://doi.org/10.1179/ 095066010X12777205875750

10. Çam G, İpekoğlu G (2017) Recent developments in joining of aluminum alloys. Int J Adv Manuf Technol 91:1851-1866. https://doi.org/10.1007/s00170-016-9861-0

11. Heidarzadeh A, Mironov S, Kaibyshev R, Çam G, Simar A, Gerlich A, Khodabakhshi F, Mostafaei A, Field DP, Robson JD, Deschamps A, Withers PJ (2020) Friction stir welding/processing of metals and alloys: a comprehensive review on microstructural evolution. Prog Mater Sci 100752:100752. https://doi.org/10.1016/ j.pmatsci.2020.100752 
12. Kashaev N, Ventzke V, Çam G (2018) Prospects of laser beam welding and friction stir welding processes for aluminum airframe structural applications. J Manuf Process 36:571-600. https://doi. org/10.1016/j.jmapro.2018.10.005

13. von Strombeck A, Cam G, dos Santos JF et al (2001) A comparison between microstructure, properties and toughness behaviour of power beam and friction stir welds in Al-alloys. In: Das SK (ed) Aluminium 2001: Proceedings of the TMS 2001 annual meeting aluminum automotive and joining symposia ; held at the TMS 2001 annual meeting in New Orleans, LA, February 12-14, 2001. TMS The Minerals Metals and Materials Society, Warrendale, pp 249264

14. Köhler T, Raab M, Regensburg A, Bergmann JP (2019) Liquid interlayer formation during torsional ultrasonic welding of EN CW004A and EN AW1050. Weld World 116:58-1194. https:// doi.org/10.1007/s40194-019-00766-5

15. Bergmann JP, Petzoldt F, Schürer R, Schneider S (2013) Solid-state welding of aluminum to copper - case studies. Weld World 57: 541-550. https://doi.org/10.1007/s40194-013-0049-z

16. Ni ZL, Yang JJ, Hao YX, Chen LF, Li S, Wang XX, Ye FX (2020) Ultrasonic spot welding of aluminum to copper: a review. Int J Adv Manuf Technol 107:585-606. https://doi.org/10.1007/s00170-02004997-5

17. Ni ZL, Ye FX (2016) Dissimilar joining of aluminum to copper using ultrasonic welding. Mater Manuf Process 31:2091-2100. https://doi.org/10.1080/10426914.2016.1221101

18. Regensburg A, Petzoldt F, Schürer R, Hellwig P, Bergmann JP (2017) Effect of local preheating during ultrasonic welding of Al$\mathrm{Cu}$ joints on strand compaction and bond formation. Weld World 61:443-451. https://doi.org/10.1007/s40194-017-0434-0

19. Zhang Y, Li Y, Luo Z, Yuan T, Bi J, Wang ZM, Wang ZP, Chao YJ (2016) Feasibility study of dissimilar joining of aluminum alloy 5052 to pure copper via thermo-compensated resistance spot welding. Mater Des 106:235-246. https://doi.org/10.1016/j. matdes.2016.05.117

20. Zhang Z, Wang K, Li J, Yu Q, Cai W (2017) Investigation of interfacial layer for ultrasonic spot welded aluminum to copper joints. Sci Rep 7:12505. https://doi.org/10.1038/s41598-01712164-2

21. Regensburg A, Petzoldt F, Benss T, Bergmann JP (2019) Liquid interlayer formation during friction stir spot welding of aluminum/ copper. Weld World 63:117-125. https://doi.org/10.1007/s40194018-0620-8

22. Braunovic M (1992) Evaluation of different platings for aluminumto-copper connections. IEEE Trans Components Hybrids Manuf Technol 15:204-215

23. Jackson RL (1982) Electrical performance of aluminium/copper bolted joints. IEE Proc C -Gener Transm Distrib 129:177. https:// doi.org/10.1049/ip-c:19820030
24. Bond NT, McGeary FL (1973) Nickel plating for improved electrical contact to aluminum. IEEE Trans Ind Appl IA-9:326-331. https://doi.org/10.1109/TIA.1973.349911

25. Lefebvre J, Galand J, Marsolais RM (1990) Electrical contacts on nickel plated aluminium: the state of the art. In: Thirty-Sixth IEEE Conference on Electrical Contacts, and the Fifteenth International Conference on Electrical Contacts. IEEE, pp. 454-460

26. Ni ZL, Ye FX (2016) Weldability and mechanical properties of ultrasonic welded aluminum to nickel joints. Mater Lett 185:204 207. https://doi.org/10.1016/j.matlet.2016.08.129

27. Balasundaram R, Patel VK, Bhole SD, Chen DL (2014) Effect of zinc interlayer on ultrasonic spot welded aluminum-to-copper joints. Mater Sci Eng A 607:277-286. https://doi.org/10.1016/j. msea.2014.03.135

28. Oberst M, Schlegel S, Grosmann S (2019) On the aging of electrical joints with a copper and an aluminum contact member. In: Proceedings of the Sixty-Fifth IEEE Holm Conference on Electrical Contacts. IEEE, Piscataway, pp 1-8

29. Oberst M, Schlegel S, Grossmann S, Willing H, Freudenberger R (2020) Impact of the formation of intermetallic compounds in current-carrying connections. IEEE Trans Device Mater Relib 20: 157-166. https://doi.org/10.1109/TDMR.2020.2971055

30. DIN CEN/TS 13388:2020-09, Kupfer und Kupferlegierungen Übersicht über Zusammensetzungen und Produkte; Deutsche Fassung CEN/TS_13388:2020_+ AC:2020

31. DIN EN 573-3:2019-10, Aluminium und Aluminiumlegierungen Chemische Zusammensetzung und Form von Halbzeug - Teil 3 : Chemische Zusammensetzung und Erzeugnisformen; Deutsche Fassung EN_573-3:2019

32. UL Standard (2014) Standard for electrical quick-connect terminals (UL 310)

33. Volkswagen AG (2013) Elektrische und elektronische Komponenten in Kraftfahrzeugen bis 3,5 t: Allgemeine Anforderungen, Prüfbedingungen und Prüfungen(VW 80000)

34. DIN EN ISO 11130:2018-06, Korrosion von Metallen und Legierungen_- Wechseltauchprüfung in Salzlösung (ISO_11130: 2017); Deutsche Fassung EN_ISO_11130:2018

35. SAE International (2009) Performance specification for ultrasonically welded wire terminations (USCAR38)

36. Abbasi M, Karimi Taheri A, Salehi MT (2001) Growth rate of intermetallic compounds in $\mathrm{Al} / \mathrm{Cu}$ bimetal produced by cold roll welding process. J Alloys Compd 319:233-241. https://doi.org/ 10.1016/S0925-8388(01)00872-6

Publisher's note Springer Nature remains neutral with regard to jurisdictional claims in published maps and institutional affiliations. 